\section{Crystallization and Preliminary Crystallographic Data of Japanese-radish $\beta$-Amylase}

\author{
Shigeo Aibara, Honami Yamashita \\ and Yuhei MORITA \\ The Research Institute for Food Science, \\ Kyoto University, Uji 611, Japan
}

Received July 4, 1977

Beta-amylase is distributed in higher plants, and the crystalline enzymes have been prepared from sweet potato, ${ }^{1)}$ barley, ${ }^{2)}$ wheat ${ }^{3)}$ and soybean. ${ }^{4)}$ As Japaneseradish (Raphanus sativus L.) roots have also been known to be a useful source, ${ }^{5)}$ Morita and Wadano ${ }^{8)}$ purified two isozymes of $\beta$-amylase, components I and II, and crystallized component I. However, both components of Japanese-radish $\beta$-amylase were less stable than those of other origins ${ }^{7)}$ and could not be obtained in a sufficient yield for further structural studies. The lability of enzyme activity is thought to result from surface denaturation or polymerization of enzyme molecules and/or the inactivation by mercaptide formation with heavy metal ions. ${ }^{8)}$

The present paper describes an improved method of purification and crystallization of Japanese-radish $\beta$ amylase in a stable form and some preliminary crystal- lographic data of the hexagonal crystal of component I. The major improvement was to purify the enzyme in the presence of $\beta$-mercaptoethanol and EDTA to prevent the effects of oxidation and of heavy metal ions on the essential sulfhydryl groups in the enzyme molecule. The dialysis against ammonium sulfate solution was effective in diminishing the surface denaturation of the enzyme protein at the later steps of purification, as compared to direct mixing with the solid salt or its saturated solution.

Japanese-radish roots (variety Nerima), $1000 \mathrm{~kg}$, were grated and squeezed through a cotton cloth, and the juice was treated with ammonium sulfate to $90 \%$ saturation. The precipitate was collected and refractionated with ammonium sulfate, and a fraction between 30 to $60 \%$ saturation was collected by filtration. The precipitate was dialyzed against $0.03 \mathrm{M}$ sodium phosphate buffer, $\mathrm{pH}$ 6.0. $\beta$-Amylase was purified by ion-exchange chromatography on CMSephadex C-50 and DEAE-Sephadex A-50 columns followed by gel filtration on a Sephadex G-100 column, in accordance with the method of Morita and Wadano ${ }^{8)}$ except the presence of $29 \mathrm{~mm} \beta$-mercaptoethanol and $45 \mathrm{~mm}$ EDTA in the elution buffer. It was noted that the enzyme in each chromatographic eluate was precipitated by dialysis against $70 \%$-saturated ammonium sulfate solution containing $\beta$-mercaptoethanol and EDTA. Finally, two chromatographically different components were obtained, which were electrophoretically identical with components I and II reported by Morita and Wadano. A solution of component $\mathrm{I}$, $28 \mathrm{mg} / \mathrm{ml}$, containing $0.1 \mathrm{M} \mathrm{NaCl}, 0.1 \mathrm{M}$ phosphate

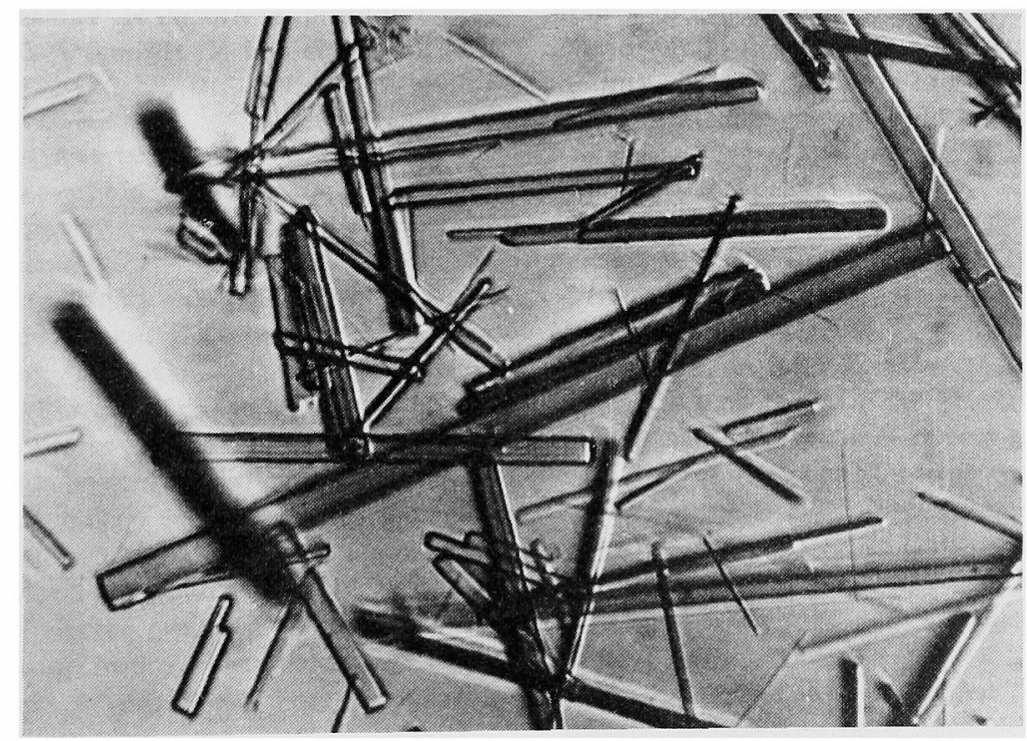

FIG. 1. Crystals of Japanese-radish $\beta$-Amylase, Component I.

The crystals were formed in $40 \%$-saturated ammonium sulfate solution containing $0.1 \mathrm{~m}$ phosphate buffer, pH 6.0,0.1 $\mathrm{M} \mathrm{NaCl}, 3.8 \mathrm{~mm}$ EDTA and $18 \mathrm{~mm} \beta$-mercaptoethanol. 
buffer, pH $6.0,3.8 \mathrm{~mm}$ EDTA and $18 \mathrm{~mm} \beta$-mercaptoethanol, was dialyzed against $40 \%$-saturated ammonium sulfate solution at $4^{\circ} \mathrm{C}$. Small crystals appeared within a day and the crystallization was completed in a week. The yield of crystalline component I was $323 \mathrm{mg}$ from $1000 \mathrm{~kg}$ of Japanese-radish roots, which was much higher than that of Morita and Wadano, $7.7 \mathrm{mg}$ from $200 \mathrm{~kg}$ of roots. Component II was also crystallized in a similar manner at $\mathrm{pH} 6.0$, and the yield was $622 \mathrm{mg}$. The specific activity of these components, I and II, with amylopectin as a substrate was 516 and $577 \mu$ moles of maltose released per min per $\mathrm{mg}$ of protein, respectively, as determined by the method of Bernfelt. ${ }^{\text {?) }}$

The large single crystals of component I were prepared by the microdiffusion method described by Zeppezauer et al. ${ }^{10)}$ The smail crystals of component I were dissolved in $0.1 \mathrm{M}$ phosphate buffer, $\mathrm{pH} 6.0$, containing $0.1 \mathrm{M} \mathrm{NaCl}, 3.8 \mathrm{mM}$ EDTA and $18 \mathrm{~mm}$ $\beta$-mercaptoethanol, and the protein concentration was adjusted to $60 \mathrm{mg} / \mathrm{ml}$. Aliquots, $200 \mu \mathrm{l}$, were dialyzed in Zeppezauer's tubes against $40 \%$ saturated ammonium sulfate solution containing $0.1 \mathrm{M}$ phosphate buffer, $\mathrm{pH} 6.0,0.1 \mathrm{M} \mathrm{NaCl}, 3.8 \mathrm{~mm}$ EDTA and $18 \mathrm{~mm}$ $\beta$-mercaptoethanol. Rodlike crystals were grown in a size of $0.2 \times 0.2 \times 2.0 \mathrm{~mm}$ within a week as shown in Fig. 1. The same procedure was employed with


to a sufficient size.

Precession photographs $\left(8^{\circ}\right)$ were taken with the crystals of component I by the use of Ni-filtered CuK $\alpha$ radiation from a Philips fine-focusing tube. Unit cell dimensions were calculated to be $a=b=67 \AA, c=208 \AA$ and $V=807,000 \AA^{3}$. The crystal belongs to a hexagonal system having the space group of $P 6_{1}$ or $P 6_{b}$. Assuming the density of crystal to be $1.25 \mathrm{~g} / \mathrm{cm}^{3}$ and the molecular weight of $\beta$-amylase component $I$ to be
58,000 daltons, ${ }^{77}$ an asymmetric unit of crystal contains one molecule of enzyme. The percentage of the protein in the crystal is about 57 . Compared with the crystal of soybean $\beta$-amylase, ${ }^{11}$ the hexagonal crystal of Japanese-radish enzyme (component I) gave unresolved individual reflections along the $c^{*}$ axis since the $c$ axis is too long. For further crystallographic analysis, a search for preparing crystals of other new crystal systems is underway.

\section{REFERENCES}

1) A. K. Balls, M. K. Walden and R. R. Thompson, J. Biol. Chem., 173, 9 (1948).

2) E. H. Fischer, K.H. Meyer, G. Noelting and A. Piguet, Arch. Biochem. Biophys, 27, 235 (1950).

3) K. H. Meyer, P. F. Spahr and E. H. Fischer, Helv. Chim. Acta, 361924 (1953).

4) J. Fukumoto and Y. Tsujisaka, Kagaku to Kogyo (Osaka), 29, 282 (1955).

5) T. Nishida, Tokyo Ika-daigaku Zasshi, 8, 113 (1959).

6) Y. Morita and A. Wadano, Bull. Res. Inst. Food Sci., Kyoto Univ., 37, 9 (1974).

7) A. Wadano and Y. Morita, ibid., 37, 19 (1974).

8) K. Visuri and M. Nummi, Eur. J. Biochem., 28, 555 (1972).

9) P. Bernfelt, "Methods in Enzymology," Vol. I, ed. by S. P. Colowick and N. O. Kaplan, Academic Press Inc., New York, N.Y., 1955, p. 149.

10) M. Zeppezauer, H. Eklund and E. S. Zeppezauer, Arch. Biochem. Biophys., 126, 564 (1968).

11) Y. Morita, S. Aibara, H. Yamashita, F. Yagi, T. Suganuma and K. Hiromi, J. Biochem., 77, 343 (1975). 